\title{
Hyperbolic Discounting in Fiscal Policy: The Case of Malaysian Government Budget
}

\author{
Putri Swastika
}

IAIN Metro

Email: swastikaputri@gmail.com

Azura Othman

CIIFP Malaysia

Email:azura.alf@gmail.com

\begin{abstract}
Thispaper examines the lag effect of interest payments on the national output represented by GDP. The lag effectimplies the observation of hyperbolic discounting in the fiscal policy. The idea is round-eyed; that the government takes on high debts to finance their spending while not factoring or placing less importanceon the cost of the interest payments. The concept of hyperbolic discounting of behavioral economics is used in this paper to explain this phenomenon in the present path of public policy which operates under an interest-based system. We conduct this analysis by examiningthe present fiscal model and its effect on the economy, wherein debt is preferredin fiscal policy framework.It appears from the findings that the trend in Malaysia's fiscal policy shows the presence of hyperbolic discounting. Shifting the debt burden to future governments and spending above revenue capacity can be seen as a manifestation of the common pool problem. Two main policy recommendations can be made. Firstly, the fiscal policy structure has to move away from the current interest-based borrowing. This is because an intrinsic feature of the interest-based system is that the risks of a debt transaction are transferred from the lender to the borrower.Secondly, the current tax structure can be simplied to improve tax compliance so as to improve tax revenue collection.Both the above policy recommendations have the potential of reducing the effect of hyperbolic discounting. The first increases the interaction between the government and the public thus enhances the governance structure of the government. The government will have to be more transparent in its dealing as the public has a vested interest in the development projects. The second enhances the first effect by providing a potential increase in tax revenue which will reduce the stress on debt servicing and the need for borrowing.
\end{abstract}

Key words:Hyperbolic Discounting, Fiscal Policy, Malaysia, Debt. 


\section{A. Introduction}

This paper examines the lag effect of interest payments on the national output represented by GDP. The lag effectimplies the observation of hyperbolic discounting in the fiscal policy. The idea is round-eyed;that the government takes on high debts to finance their spending while not factoring or placing less importanceon the cost of the interest payments. This is typical in the present regime of fiscal framework where the government tends to solve their consumption problem(due to deficits and/orlack of funds forpublic projects) by taking on interest-bearing debts that expose the country to risks. The concept of hyperbolic discounting of behavioral economics is used in this paper to explain this phenomenon in the present path of public policy which operates under an interest-based system. We conduct this analysis by examiningthe present fiscal model and its effect on the economy, wherein debt is preferredin fiscal policy framework.

It is argued that interest paymenton debtsreduces the potential optimal growth of the economy. There are two reasons for that. First, if the debt was incurred to finance development expenditures (or sometimes due to political reasons), it may potentially affect the economic productivity positively in the short-term yetcarries negative effects in the longer-term by increasing thefiscal burden and public indebtedness. This is especially so when the rate of growth of the economy arising from the development projects is lower than the rate of interest on the rising debts. Increase in the burden of debt servicing may eventually necessitatesan increase in tax rates if revenue from other sources is not forthcoming.Secondly, in the case where the debt is accumulatedto plug deficits (orto prop up an economyin difficulty), funds used for interest payments at time $t$ reduces the allocationfor developmentexpenditure also at tand continues throughout time $n$. It is so, because the interest payment requires an allocation system across the maturity structure (Teles \& Cesar, 2014). Various studies have shown that interest payments are a "harsh constraint" to productive activities (Presbitero, 2005).

Various studies have also documented the limits of debt in fiscal policy to increase economic growth (Cunningham, 1993; Dornbusch, 1984; B. C. Reinhart \& Rogoff, 2010; C. M. Reinhart, Reinhart, \& Rogoff, 2012; Siddiqui \& Malik, 2001). However, most of these studies merely discussthe effects of debt on the economywhile some extend the study to measurevarious countries' threshold for debt-tolerance.Hencemore often than not, the repercussion of debt, that is interest-payments, and its effect towards the economy is often overlooked. Recent study byTeles \& Cesar(2014) examined the impact of public debts and fiscal limits on the economy from distinguished perspective of intergenerational 
income transfer; that the income flows from the younger generation to service the interest payments of public debt incurred by the older generation. Therefore, we suggest that the debt problem is analogous to the ice berg that any ship should avoid to prevent a calamity. The probem is manifested bythe interest-based financial system that creates a divergence between the financial and real sector of the economy. Using non-linear techniques, Wavelet and Vector Autoregression, this effect can be captured in the negative lag effects of interest payments on the output of a country. In this paper, the effect is examined on the fiscal situationof Malaysia.

This paper is divided into five sections. A review of the concept of the present fiscal framework, hyperbolic discounting, as well as previous studies are presented in the second section. Research methodology and data analysis are discussed in the third and fourthsections of this paper, before a policy recommendation and the conclusion are presented in section five.

\section{B. Literature Review}

Fiscal policy is the use of the government's power to tax and spend to influence economic activities (Othman \& Mirakhor, 2013, p. 330). The government sets the tax rates, spending, and budget balances over the economic cycle to ensure a sound and stable economic performance. The government can do fiscal adjustments by raising tax rates or decreasing spending in order to increase the revenue and/or narrow the gap of deficit. When government undertakes fiscal stimuli, it decreases the tax rates or gives out remission or increases public expenditure to stimulate private sectors investment and consumption.Alternatively, the government might undertake a combination of adjustments simultaneously in order to achieve a desired economic result.Therefore, fiscal policy depends much upon several variables such the objective, the state of the budget, and sometimes the political games behind it.

Among the functions of fiscal policy areto set an optimal allocation of funds and distribution of income throughout each segment of the economy.That is, how to use government income at its best. However, recent studies in political economy suggest that in countries of unstable political system, current government runs deficits because of political reasons (Persson and Svensson, 1989; and Tabellini and Alesina, 1990 as cited from Huber \& Runkel, 2008). The present regime run deficits and acquired debt to fuel their lavish public spendinghence enhancing their re-election probabilities.Or sometimes, the present regime simplydisregards the fiscal burden of future government once they realizethat they cannot defend their political position any longer.Furthermore, the recent sovereign debt crisis in the EU showed us that 
allocation of income has become less significantin comparison with the problem of acquiring debt to finance deficits.

In the past decades, there is a growing number of economists who have found that the use of interest-bearing debt carries an adverse effect to the economy.For instance, a study by Cunningham(1993) found that the growth of a nation's debt burden negatively impacts economic growth and therefore endorses the arguments for debt reduction to support economic growth. In 1996, IMF and the World Bank jointly launched debt relief program for the HIPC (Heavily Indebted Poor Countries) highlighting the negative relationship between debts and economic performance. Presbitero (2005) also confirmed a negative relationship between debt and growth in the poor countries and asserted further on the effect of debt in decreasing quality and efficiency of investment as well as shaking macroeconomic stability.Hence, this development in macroeconomic fields hints the insignificance (or lesser significance) of assumptions in the classical macroeconomic theory.

Conventional macroeconomic policy is built upon two essential assumptions. They are (1)"deficits are completely bond-financed" and (2)"fiscal and monetary credibility is sound"(Langdana, 2002). Amongst the deficit financing alternatives in the conventional monetary policy, bond-financed deficits is considered to be a better alternative than options such as monetization and debt repudiation. Langdana(2002, p. 33)asserted that almost $100 \%$ of US interest expenses on government were funded by another debt (inflows from the T-bills). Monetization, or issuing (printing) more money to finance government deficit, is considered to pose a danger to the economy as it entails higher inflation rate. This looks paradoxical, in our opinion, because government bond is classifiedas risk-free assets;owing to its distinguished feature of being guaranteed by the government who can print money, as classical textbooks assert. The third option for financing, debt repudiation, is simply a national default on debt by declaring an inability to pay. Due to its negative effect in relation with foreign countries (i.e. the creditor countries) and other potential effectsthat may impair other national interests, such as trade and capital embargo, this option is perceived to be not a viable financing option. Lastly, government could finance deficits through one-time sale of national resources, which is the last option that a government would ever take. Regardless of its irrelevance to contemporary macroeconomic condition, many theorist and policy makers design economic policy using these crucial assumptions.

How realistic "the fiscal and monetary credibility" assumption is also questioned. It is assumed that the central bank has a good reputation of monetary discipline. The central bank should maintain its independence from the 
government and parliament and would not be pressured by the government to monetize deficits. The assumption also implies a critical message that government does not steer fiscal policy for the sake of their power re-enforcement. In other words, fiscal policy of the government isvested towards the best interest and development of the society and notfor mere political interest. Here, it is also assumed a stablepolitical climate exists, as it is the condition that ensures a stable macroeconomic condition. Again, regardless of its relevance to reality, this assumption omits the influence of politicians and lobbyists in the fiscal and monetary policy-making.

Nevertheless, the present theoretical framework of fiscal policy also acknowledges both sides of the coin. Plethora of studies and contemporary macroeconomic texts highlight the rule of thumb for bond-financed deficits sustainability. Bond-financed deficits is said to be sustainable as long as the inflation adjusted government bond's coupon rate is less than the growth rate of the economy. And it is not sustainable when the growth of the economy could not meet the growth of government debt. In other words, bond-financing is an unsound policy when the macroeconomic conditions of the country is instable as it will let the interest rate to rise and subsequently "crowd out" private sectors to expand credit or to take investment. If continued, money (or credit) becomes scarce and the macroeconomic variables such as unemployment, and prices increase. Here, the real interest on government debt exceeds the growth rate of the economy.

Another common rule of thumb for bond-financed deficits sustainability is implied in the budget deficit-to-GDP ratio. If the ratio is less than $5 \%$, then it is said to be sustainable. The Maastricht Treaty imposes 3\% deficit/GDP ratio for EU members yet allows toleration up to a certain extent where the deficit is considered to have declined significantly and continuously narrows the gap with the $3 \%$ reference value. More stringently is the product post-Maastricht Treaty, that is the Stability and Growth Pact (SGP). SGP keepsthe reference value of $3 \%$ annual deficits-to-GDP ratio, but imposes a penalty (mandatory deposits that are transformed into fines) for member countries with excessive deficits which fall beyond the tolerated thresholds(Calmfors, 2005). Therefore, itadvocates member countries to adjust their fiscal behavior in order to have balanced budget as their medium-term objective (Eichengreen and Wyplosz, 1998)1.All in all, these measures are not made to control or benchmark the

\footnotetext{
1Eichengreen and Wyplosz list five benefits of enacting the SGP. The first is to prevent inflationary debt bailouts. Inflationary debt bailouts is costly for countries under an union, such as EU nations, because excessive debt levels that evoke bailouts will likely to have contagious effect to the currency, hence affecting financial stability and macroeconomic condition of other member countries. Secondly, is to neutralize inflationary pressure more generally. Thirdly, is to offset
} 
sustainability of a country's fiscal policy. Rather, they are the tools that provide an early warning and sensing system for the government beforefalling over the fiscal cliff. Therefore, the conventional economists and policy makers have begun to see the untenable side of borrowing.

The argument here is that interest-payment reduces the optimal output of indebted countries. As the government suffers from budget deficits and follows conventional prescription to meet the deficit (that is loan), the government pushes the fiscal burden forward to $t+n$ period, hence forsakes the optimal output of the country at $t+n$ period. In the case of today, where a country pays their debtobligation by piling up another debt (Ponzi-Game scheme), the trade-off between borrowing and output becomes much greater. As the debt accumulates, the cost of borrowing becomes greater, the interest-payment compounds, and the time range for maturity becomes much longer. Logically, this will lead to further reduction of the national output in the future and ultimately the people of the country suffer. It is a vicious cycle that interest-rate system builds; that indebtedness creates other source of indebtedness through the interest-rate mechanism. In behavioral economics, this phenomena is called hyperbolic discounting.

Hyperbolic discounting in economics predicts the dynamic inconsistent time-preferences of an economic agent in the decision-making process. The theory asserts that an agent holds and acts on preferences at one point in time that contradict the preferences at a later period (Harrison \& Lau, 2005). In other words, the agent discounts the value of today greater than tomorrow's rewards, hence prefers the smaller but immediate payoffs. This behavior is well-observed in daily life, for instance, we use credit card excessively when a "sale" sign is put on without worrying about the payment at the end of period.In an interest-based financial system, creditors favorimmediate payment for loans at a lower interestrate for short-term debt and increasethe rate along with the maturity structure. In the case where debtors are not fundamentally sound, creditors are hardly willing to forgive the debt-payment. Whereas on the other side, debtors want to have a lower initial debt-payment in a non-traditional amortization structure (Ghent, 2011). Because of that, hyperbolic discounting engenders a coordination problem in the society (Laibson, 1994) and seems to reason out why the present financial crisis happened(Gärling, Kirchler, Lewis, \& van Raaij, 2010).

political bias towards excessive deficits. High debts make the public finances more fragile, reduce the effectiveness of monetary policy, increase fiscal crowding out (since additional government spending by raising interest rates, thereby raises debt service costs), raise the deadweight cost of taxation, and make funding social security liabilities more difficult. Fourthly, is to internalize international interest rate spillovers associated with uncoordinated fiscal policies. And the fifth is to encourage policy co-ordination (Eichengreen and Wyplosz, 1998, pp. 71-78). 
There is an ambiguous relationship between budget and GDP. Budget deficit is justified as long as the economy is improved. And as discussed earlier, borrowing is the main (if not the only) source for financing deficits, according to mainstream doctrine. On the other side, growing numbers of economists view that balanced budget is the better policy, as it may limit the effect of cognitive dissonance of the government or in an inter-regime government, shown by hyperbolic discounting behavior. The example for this is the Swiss Debt Brake (SchweizerSchuldenbremse) ${ }^{2}$. However, indeed performance of the economy is multi-dimensional, i.e. it can be represented by general indicators such as Gross Domestic Output, or specific variables such as inflation-rate, exchange-rate, and unemployment-rate. Even nowadays, public debt is one of the variables that many researchers refer when it comes to measuring economic performance. Therefore, this trend indirectly infers that budget deficits (where public debt is used to finance it) lead to sluggish economic performance of a country.

In the case of Malaysia, the country has been suffering fiscal deficits for the last 16 years.

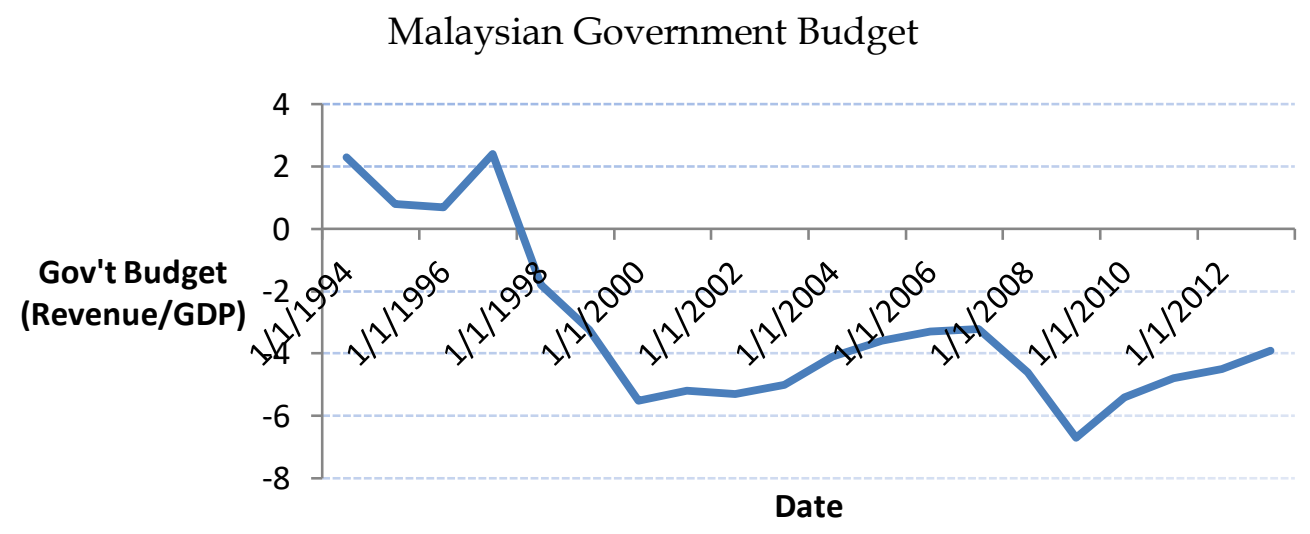

Malaysian Government Debt

2The Swiss "debt brake", or also known as "debt containment rule", is a fiscal rule aimed at financing expenditures through current revenues instead of new debt. This budget rule is applied in concert with a constitutional upper limit on the main tax rates, hence preventing the government to overuse the budget and manage the budget through tax ratesadjustment. The rule is designed for the government, at anytime and at any regime, to follow structurally balanced budget (Geier, 2011). 

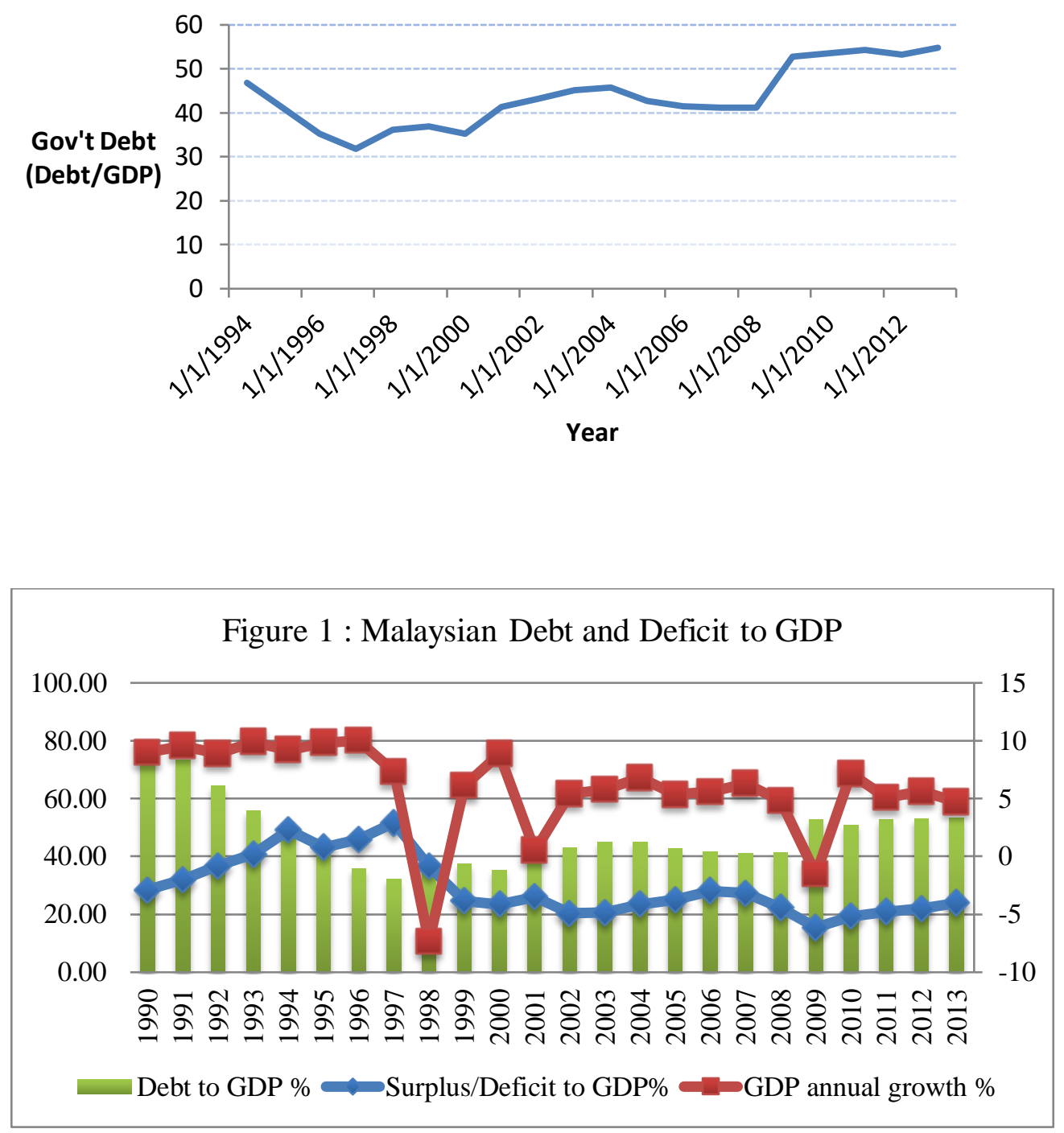

Malaysia is chosen as the case study as it has been enjoying a rather stable economic growth (apart from during the two major crisis of 1998 and 2008) yet recordsa rising trend in debt-to GDP ratio and a persistent deficit.Its tax revenue is also on the increase but the increase in expenditure has risen at a higher rate. It is also worth noting that the development expenditure in government spending has been on a declining trend as opposed to the increasing trend of operating expenditure (Figure 2). On first analysis, it appears that the government is spending beyond its means and more towards government administration rather than development projects that will benefit the society, and it has been financing the additional spending with more and more borrowing. Therefore, this study will examine whether this development can be explained by hyperbolic discounting. 
Figure 2 : Malaysian Government Revenue and Expenditure

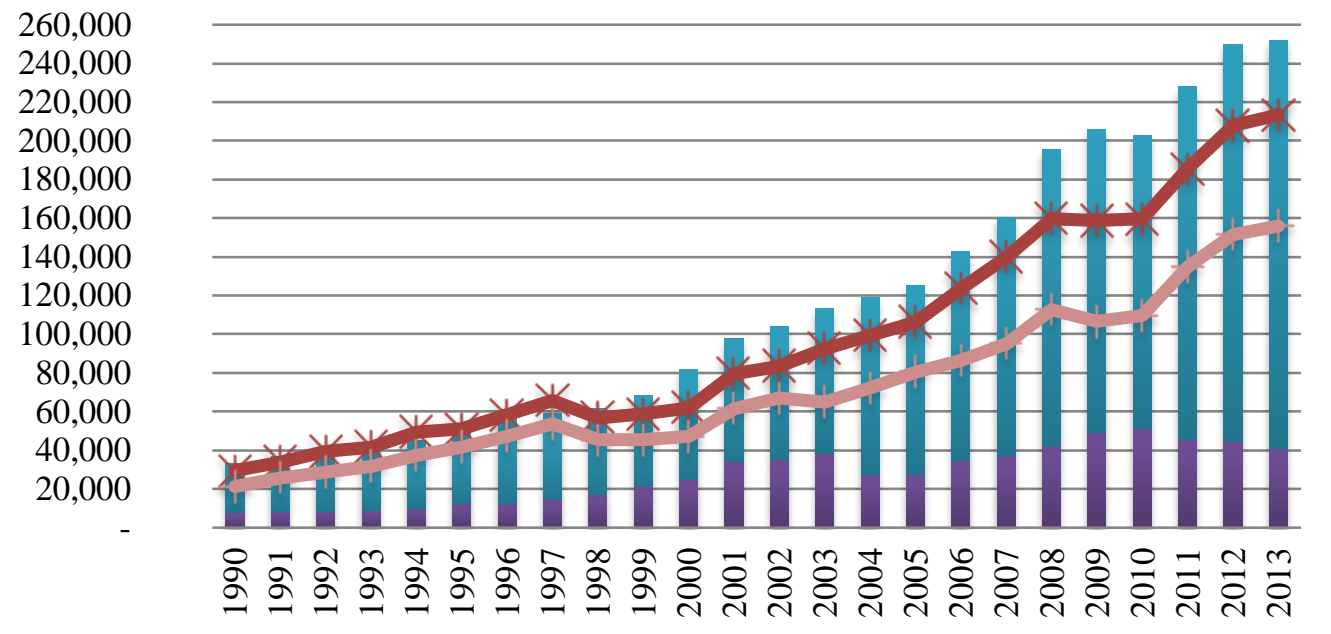

Development Exp $\quad$ Operating Exp

\section{Model \&Research Methodology}

Hyperbolic discount functions are characterized by a high discount rate over short horizons and a low discount rate over long horizons (Laibson, 1997). Events in the future at time $t$ are discounted using hyperbolic discount factor; $f(t)=(1+\alpha t)^{-\beta / \alpha}$, and $\alpha, \beta>0$. The $\alpha$ is the constant discounting, and $\beta$ is the slope. Such discount functions imply a monotonically falling discount rate $\{f(t)\}$ which shows a conflict between today's and future preferences; that today's value carries higher discount factor (hence, short-term is desirable) while long-term implies a lower discount factor (hence, is not preferred). It is said that the function captures a human problem of "preference reversals".

One important study which analyze hyperbolic discounting in fiscal policy is done byHuber \& Runkel(2008).From their study, there are three important observations we could learn. First, public deficits are positive even if public expenditures are constant. Secondly, government tends to borrow more than its repays. And thirdly, the study reveals that hyperbolic discounting renders a borrowing rule inefficient. These three observations imply the commitment problems which shows that government "changes the initial plan and chooses lower tax revenues" in the short-run. And in terms of policy, in the case of no-PonziGame, the optimal outstanding government's liabilities "cannot exceed the present value of the maximum feasible tax revenues" (Huber \& Runkel, 2008).

To demonstrate the link between the service of debt and government liabilities, we emulate model from Huber\&Runkel (2008).

$b_{t}=(1+r) b_{t-1}+g_{t}-\tau_{t}$

where $b_{t}$ is the public debt at period $\mathrm{t}$ which is equivalent to public debt at the beginning of $t$ (from $t-1$ period) and the interest payment and government 
expenditure $\left(g_{t}\right)$ minus tax revenue $\left(\tau_{t}\right)$ at time $t$. Therefore, the liabilities of government at time $t$ is represented by the present value of future government expenditure and its outstanding debt.

$l_{t}=\sum_{i=0}^{\infty} \frac{g_{t+i}}{(1+r)^{i}}+(1+r) b_{t-1} \ldots \ldots$

From Huber \&Runkelmodel above, we derive government total outstanding liabilities of period $t$ when Ponzi-game scheme occurred.

$l_{t}=\sum_{i=0}^{\infty}\left(\frac{g_{t+i}+b_{t+i}}{(1+r)^{i}}\right)+(1+r) b_{t-1} \ldots \ldots$

Under hyperbolic time preference, we can write the Euler's approximation for continuous trajectories as:

$l_{t}=(1+r) b_{t-1}+\sum_{i=0}^{\infty}\left(\frac{g_{t+i}+b_{t+i}}{(1+r)^{i}}\right) \Delta t \ldots$

The total outstanding liabilities of period $t\left(l_{t}\right)$ equal to the present value of future government expenditure and public debt plus the outstanding debt at the beginning of period $t$.It measures the financial pressure for budget at time $t$. Posing the assumption that tax deficit reduces the welfare effect, the constraint for the government budget would be $l_{t} \leq \tau$ otherwise deficit will occur. In the scenario where the pressure surmounts, the government has limited policy choices except to increase the tax revenue figure by increasing tax rates -although it does not guarantee an increase in the revenue (the Laffer curve arguments ${ }^{3}$ ) and improvement in the budget.

The relationship between budget, GDP, and hyperbolic discounting is explained next. Consider this equation:

$Y=C+G+I+(X-M)$

Where, $Y$ is the national output (reflected in GDP); $C$ is the household consumption, $\mathrm{G}$ is the government expenditure, $\mathrm{I}$ is the private sectors' fixed investment, and $\mathrm{X}-\mathrm{M}$ is the trade surplus (or deficits). Now, we assume that $\mathrm{Y}$ is absolutely dependent onG, and $\mathrm{G}$ is represented in government budget. In this economy, households and private sectors only consume and produce when incentive from the government is available. Similarly, $\mathrm{X}-\mathrm{M}$ variable also followsG.Hence, C, I, and (X-M) are highly correlated with G. Thus, Y only corresponds to the changes in $G$ in a positive linear relationship. When the government expenditure suffers from the policy maker's hyperbolic discounting, the relationship becomes:

$\bar{G}_{t}=\frac{\left(b_{t}+\tau_{t}\right)}{f_{t}}$

In economics, the Laffer curve is a representation of the relationship between possible rates of taxation and the resulting levels of government revenue. It illustrates the concept of taxable income elasticity - taxable income will change in response to changes in the rate of taxation. It postulates that no tax revenue will be raised at the extreme tax rates of $0 \%$ and $100 \%$ and that there must be at least one rate where tax revenue would be a non-zero maximum. The concept of Laffer Curve was attributed to the writings of a famous Muslim scholar IbnKhaldun 
where $f_{t}=(1+\alpha t)^{\beta / \alpha}$. Substituting $b_{t}$ with equation (1) and adjusting with Euler's approximation, we have:

$\bar{G}_{t}=f_{t}^{-1}\left((1+r) b_{t-1}\right) \Delta t$

As in this economy $\bar{Y}_{t}=\bar{G}_{t}$, it is shown from equation (6) that interest-rate and debt paid at time $t$ affects the national output of the country at $\Delta t$ period.

Figure 3 : Hyperbolic Discounting in Fiscal Policy

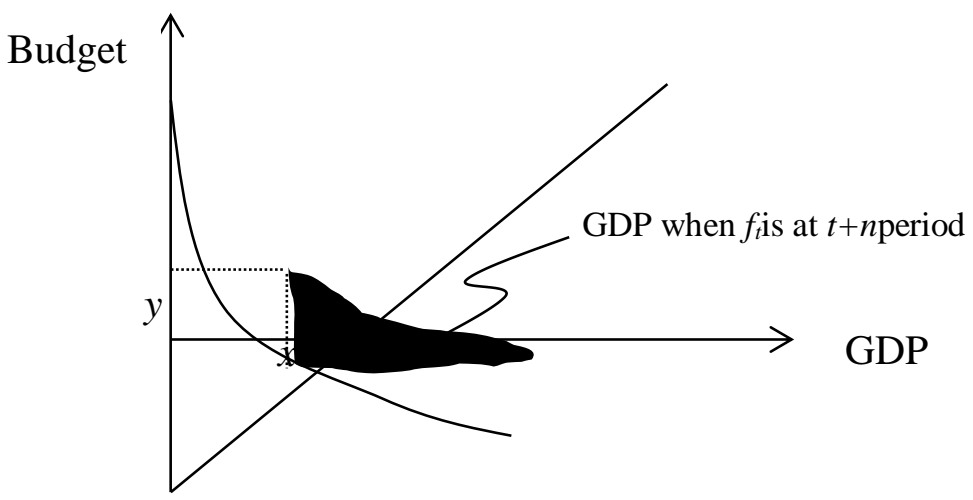

This observation is analyzed using a simple correlation analysis. The reason for this is basic. The correlation between two variables at time tcanbe explained in the equation (8).

$r_{x y}=\frac{n \sum x_{t} y_{t}-\sum x_{t} \sum y_{t}}{\sqrt{n \sum x_{t}^{2}-\left(\sum x_{t}\right)^{2}} \sqrt{n \sum y_{t}^{2}-\left(\sum y_{t}\right)^{2}}}$

Hence, in order to capture the interval effect of the correlation, the equation is adjusted as follows:

$r_{x y}=\frac{n \sum x_{t} y_{t+i}-\sum x_{t} \sum y_{t+i}}{\sqrt{n \sum x_{i}^{2}-\left(\sum x_{i}\right)^{2}} \sqrt{n \sum y_{t+i}^{2}-\left(\sum y_{t+i}\right)^{2}}}$

where $(t+i)-t$ is the $\Delta t$. And, in order to confirm that the regression suffers from the lag, $\operatorname{AR}(p)$ model is employed here.

\section{Findings \& Discussion}

From our correlation analysis, following equation supports our hypothesis.

$$
r_{i, Y}=\frac{n \sum i_{t} Y_{t+2}-\sum i_{t} \sum Y_{t+2}}{\sqrt{n \sum i_{t}^{2}-\left(\sum i_{t}\right)^{2}} \sqrt{n \sum Y_{t+2}^{2}-\left(\sum Y_{t+2}\right)^{2}}}
$$

As shown in Figure 3, when interest payment $(i)$ is paid at, say first quarter, GDP at the third quarter will decrease. In other words, the correlation between interest payment and GDP is negative at lag 2, as when the interest payment rises (or is paid), two periods after the payment the GDP declines. However, this relation does not appear if lag is not introduced.

Figure 4 : Correlation between Interest Payment and GDP at lag 2 


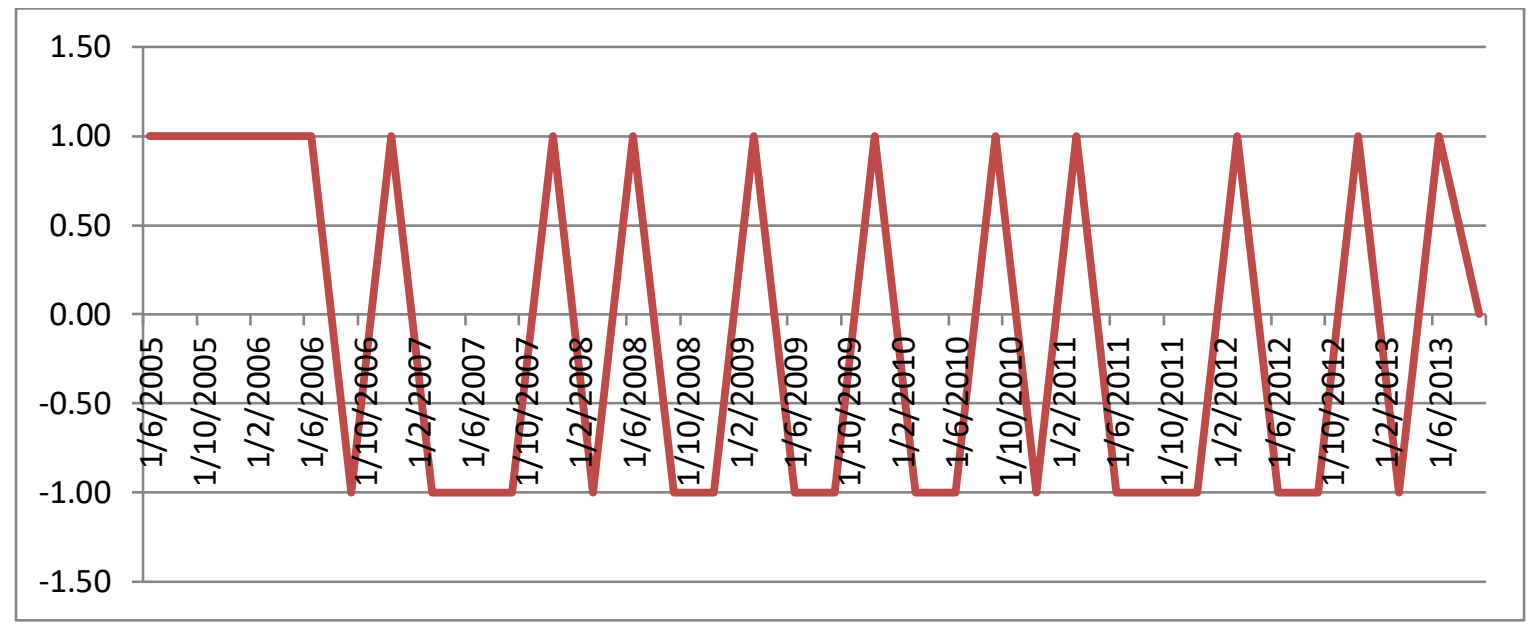

Robustness Check: Least Square Analysis

From ordinary Least Square, we have the following estimated equation:

$$
\begin{array}{ccc}
\text { GDP }=0.239 * \text { GEX }+0.358^{*} \text { INTEREST_PMNT }+6.597 \\
(0.001)^{*} \quad(0.012)^{*} & & (0.000)^{*} \text { R-Squared: } 0.662 \\
\text { R-Squared: } 0.662 & \text { AIC } & :-1.629 \\
\text { F-Statistic }: 24.503 & \text { SC } & :-1.486 \\
\text { Prob(F-Stat): } 0.000 & \text { DW Stat } & : 1.314
\end{array}
$$

Figure 5: Actual, Fitted Residual Graph

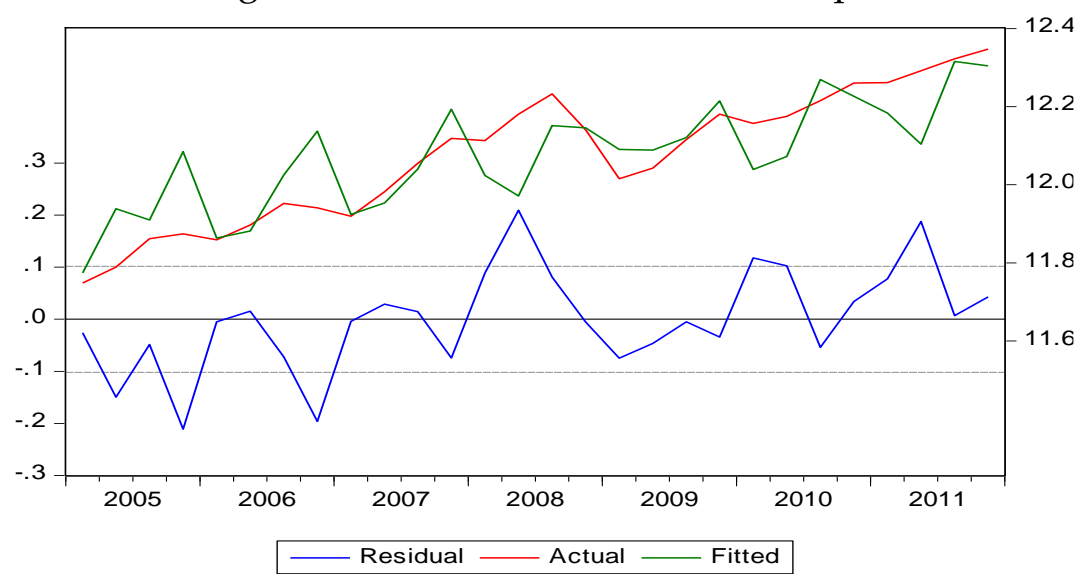

The DW Stat shows suspicion that serial correlation appears in the estimated model. Hence, we conduct Breusch-Godfrey Serial Correlation LM Test.

Breusch-Godfrey Serial Correlation LM Test:

\begin{tabular}{llll}
\hline \hline F-statistic & 4.364925 & Prob. $F(1,24)$ & 0.0475 \\
Obs*R-squared & 4.308769 & Prob. Chi-Square(1) & 0.0379 \\
\hline \hline
\end{tabular}


The result from LM Serial Correlation confirms our lag correlation analysis. Then, we compare the equation with first difference lag and AR(1) model. Table 5 - Equation with First Difference Lag

\begin{tabular}{ccccc}
\hline \hline Variable & Coefficient & Std. Error & t-Statistic & Prob. \\
\hline \hline C & 0.098324 & 0.781056 & 0.125886 & 0.9010 \\
GEX & 0.008474 & 0.037890 & 0.223653 & 0.8252 \\
INTEREST_PMNT & 0.090866 & 0.066796 & 1.360346 & 0.1881 \\
GDP(-1) & 0.983772 & 0.115579 & 8.511686 & 0.0000 \\
GEX(-1) & -0.099032 & 0.038024 & -2.604467 & 0.0166 \\
INTEREST_PMNT(- & & & & \\
1) & 0.042186 & 0.066435 & 0.634994 & 0.5323 \\
\hline \hline R-squared & 0.938724 & Akaike info criterion & -3.223439 \\
F-statistic & 64.34225 & Schwarz criterion & -2.935475 \\
Prob(F-statistic) & 0.000000 & Durbin-Watson stat & 1.466741
\end{tabular}

Table 6 -AR(1) Model

\begin{tabular}{lcccc}
\hline \hline Variable & Coefficient & Std. Error & t-Statistic & Prob. \\
\hline \hline C & 11.66173 & 0.577121 & 20.20672 & 0.0000 \\
GEX & 0.053163 & 0.022912 & 2.320325 & 0.0295 \\
INTEREST_PMNT & 0.019212 & 0.044858 & 0.428283 & 0.6724 \\
$\quad$ AR(1) & 0.940435 & 0.059811 & 15.72341 & 0.0000 \\
\hline \hline R-squared & 0.929490 & Akaike info criterion & -3.231225 \\
F-statistic & 101.0653 & Schwarz criterion & -3.039249 \\
Prob(F-statistic) & 0.000000 & Durbin-Watson stat & 1.428555
\end{tabular}

From the AIC and Schwarz value, AR(1) model seems to be preferred than the previous differential lag model. Overall, this result confirms our correlation analysis that there is interval effect in the model. 


\section{E. Policy Recommendation \&Conclusion}

It appears from the findings that the trend in Malaysia's fiscal policy shows the presence of hyperbolic discounting. Even though the current governmentis the only government that has ever ruled the country since independence, which is rather contrary to the normal belief that hyperbolic discounting happens in inter-regime governments, the study finds that high spending and borrowing seems to favour the payoffs now rather than in future. This can actually be explained by the increase in operating expenditure in recent years. Lack or suppressed check and balance may have contributed to imprudent spending. Findings of the Auditor General's Audit Report in recent years have highlighted this issue. Shifting the debt burden to future governments and spending above revenue capacity can be seen as a manifestation of the common pool problem. It is generally accepted that the common pool problem arise when the recipients of public spending (or tax advantages) fail to internalise the costs that they impose on all other taxpayers. The increasing threat of the Opposition Party in the last two general elections has also prompted the government to resort toshort-term "public-appeasing" measures in the form of one-off cash payments to lowincome households and other benefits to targeted sectors of the population. As a result, tax reforms in the form of introduction of a Goods and Services Tax (GST) and subsidy rationalization exercisehave to be undertaken in order to reduce the persistent fiscal deficits. This is an illustration of "passing the buck" of spending by the government administration to the current and future taxpayers.

In view of the above, two main policy recommendations can be made. Firstly, the fiscal policy structurehas to move away from the current interestbased borrowing. This is becausean intrinsic feature of the interest-based system is that the risks of a debt transaction are transferred from the lender to the borrower. The rate of return to the lender is guaranteed, regardless of the outcome of the business undertaking of the borrower. This cuts off the relationship between the project for which the funds are needed and its financing. The compounding of interest exacerbates the situation resulting in a divergence between the financial and real economy.Additionally, interest-based debt instruments exacerbate income distribution bias towards higher income group. These instruments are normally sold wholesale and in large denominations such that only the more economically able segment of the population such as banks and financial institutions, high net worth individuals or foreign investor are able to buy them. In order to circumvent these undesireable consequences, an incentive structure has to be put in place to encourage risk sharing rather than risk transfer.The concept of risk sharing is a distinctive feature of Islamic Finance where social justice and equity is of 
paramount importance. For instance, an alternative financing structure of government projects can be undertaken with public participation through the issuance of participation shares in a portfolio of identified government projects. The participation shares, which is benchmarked against the rate of return of the economy, can be issued in low denomination to enable onwership by the general public.This can also ease the stress on existing debts apart from opening opportunity for the economic pie to be shared by a larger segment of population.The adoption of risk sharing financing is also in line with the Malaysia's status as an Islamic country.

Secondly, the current tax structure can be simplied to improve tax compliance so as to improve tax revenue collection. Current tax system has rules that require expert advice whilst at the same time encourages the tax savvyto find creative loopholes to reduce or avoid tax.The introduction of GST may increase the government coffers but at the expense of the lower and middle income group which makes up nearly $80 \%$ of the population of Malaysia. It seems that the burden of debt (held by the higher income group) is being passed on to the lower and middle income group. A more simplified tax system would be the flat tax rate system which is easier to administer. At the same time, a fairer way of generating more tax revenue is to introduce a tax on wealth. This will ensure that tax is paid according to the ability to pay. Given that $20 \%$ of Malaysians control 54\% of wealth in Malaysia4, the introduction of GST will hit the poor more than a wealth tax will do to the rich.

Both the above policy recommendations have the potential of reducing the effect of hyperbolic discounting. The first increases the interaction between the government and the public thus enhances the governance structure of the government.The government will have to be more transparent in its dealing as the public has a vested interest in the development projects. The second enhances the first effect by providing a potential increase in tax revenue which will reduce the stress on debt servicing and the need for borrowing.

\section{References}

Calmfors, L. (2005). What Remains of the Stability Pact and What Next? Stockholm.

Cunningham, R. T. (1993). The effects of Debt Burden on Economic Growth in Heavily Indebted Developing Nations.pdf. Journal of Economic Development, 18(1).

Dornbusch, R. (1984). External Debt, Budget Deficits, and Disequilibrium Exchange Rates. Cambridge, Massachusetts.

\footnotetext{
${ }^{4}$ Quoted in http:/ / www.nationsencyclopedia.com/economies/ Asia-and-thePacific/Malaysia-POVERTY-AND-WEALTH.html
} 
Gärling, T., Kirchler, E., Lewis, A., \& van Raaij, F. (2010). Psychology, Financial Decision Making, and Financial Crises. Psychological Science in the Public Interest.

Geier, A. (2011). The Debt Brake -the Swiss Fiscal Rule at the Federal Level (No. 15). Berne, Switzerland.

Ghent, A. C. (2011). Subprime Mortgages, Mortgage Choice, Hyperbolic Discounting. Harrison, G. W., \& Lau, M. I. (2005). Is the Evidence for Hyperbolic Discounting in Humans Just an Experimental Artefact? Behavioral and Brain Sciences, 28(5), 657. doi:http:/ / dx.doi.org/10.1017/S0140525X05290118

Huber, B., \& Runkel, M. (2008). Hyperbolic Discounting, Public Debt, and Balanced Budget Rules. Scottish Journal of Political Economy, 55(5), 543-560.

Laibson. (1997). Golden Eggs and Hyperbolic Discounting. The Quarterly Journal of Economics1, (May).

Laibson, D. I. (1994). Hyperbolic Discounting and Consumption. Massachusetts Insittute of Technology.

Langdana, F. K. (2002). Macroeconomic Policy: Demistifying Monetary and Fiscal Policy (eBook.). New York: Springer. doi:10.1007/978-1-4757-3646-5

Othman, A., \& Mirakhor, A. (2013). Islam and Development: Policy Challenges. In Z. Iqbal \& A. Mirakhor (Eds.), Economic Development and Islamic Finance. Washington D.C.: The World Bank. doi:10.1596/978-0-8213-9953-8

Presbitero, A. F. (2005). The Debt-Growth Nexus: A Dynamic Panel Data Estimation. In 46 Riunione Scientifica Annuale. Naples: the Societa Italiana degli Economisti.

Reinhart, B. C., \& Rogoff, K. (2010). Why we should expect low growth amid debt, 8844.

Reinhart, C. M., Reinhart, V. R., \& Rogoff, K. S. (2012). Debt Overhangs: Past and Present. Cambridge, Massachusetts.

Siddiqui, R., \& Malik, A. (2001). Debt and Economic Growth in South Asia. The Pakistan Development Review, 40(4), 677-688.

Teles, V. K., \& Cesar, C. (2014). Public debt and the limits of fiscal policy to increase economic growth. European Economic Review, 66, 1-15. doi:10.1016/j.euroecorev.2013.11.003 